\title{
Barriers to gene flow along the Brazilian coast: a synthesis and data analysis
}

\author{
Nuno Martins ${ }^{1}$, Leonardo Macagnan $^{2}$, Valéria Cassano ${ }^{3}$, and CARLOS GURGEL ${ }^{4}$ \\ ${ }^{1} \mathrm{USP}$ \\ ${ }^{2}$ Federal University of Santa Catarina \\ ${ }^{3}$ Universidade de São Paulo \\ ${ }^{4}$ Universidade Federal de Santa Catarina
}

February 17, 2021

\begin{abstract}
Barriers to gene flow (BGF) play a pivotal role in the dynamics of population genetics promoting genetic differentiation, thus, are inexorably associated with the development and maintenance of phylogeographic structure. Phylogeographic structure resulting from BGF represents data that help the management of natural genetic resources, aiding in the recognition of areas of conservation interest. Several geographic and oceanographic processes found along the Brazilian coast have been proposed as BGF. However, no consensus exist identifying which of them represents the most important in shaping biodiversity. Therefore, this study provides a synthesis of the scientific literature on Brazilian marine phylogeography and used published data to build datasets that allowed us apply linear ( $\mathrm{lm}$ ) and generalized additive models (gam) to identify spatially congruent phylogeographic breaks among marine species (as areas of high BGF frequency occurrence). Lm identified a significant negative correlation between the occurrence of BGF and latitude, suggesting that population in the tropics are genetically more structured than in higher latitudes. This result bears strong association with the latitude species diversity gradient observed worldwide. Gam identified Cape São Roque $\left(05^{\circ} 28^{\prime} \mathrm{S}\right)$ as the main BGF for populations with continuous distribution along the Brazilian coast. Cape São Roque is located near the center point region where the South Equatorial Current splits into the northward North Brazil Current and the southward Brazil Current. This study represents the first literature synthesis of Brazil's marine phylogeography and provides a novel explicit quantitative approach to comparative phylogeography.
\end{abstract}

\section{Barriers to gene flow along the Brazilian coast: a synthesis and data analysis}

Nuno T. Martins ${ }^{1,3,}{ }^{*}$, Leonardo B. Macagnan ${ }^{2}$, Valéria Cassano ${ }^{1}$, Carlos Frederico D. Gurgel ${ }^{2}$

${ }^{1}$ Universidade de São Paulo, Instituto de Biociências, Departamento de Botânica, São Paulo, SP 05508-090, Brazil

${ }^{2}$ Universidade Federal de Santa Catarina, Centro de Ciências Biológicas, Departamento de Botânica, Florianópolis, SC 88040-900, Brazil

${ }^{3}$ ORCID: https://orcid.org/0000-0003-1912-0443

${ }^{*}$ Corresponding author: nunotmartins@usp.br

Running title : Brazilian marine phylogeography

\section{Abstract}

Barriers to gene flow (BGF) play a pivotal role in the dynamics of population genetics promoting genetic differentiation, thus, are inexorably associated with the development and maintenance of phylogeographic 
structure. Phylogeographic structure resulting from BGF represents data that help the management of natural genetic resources, aiding in the recognition of areas of conservation interest. Several geographic and oceanographic processes found along the Brazilian coast have been proposed as BGF. However, no consensus exist identifying which of them represents the most important in shaping biodiversity. Therefore, this study provides a synthesis of the scientific literature on Brazilian marine phylogeography and used published data to build datasets that allowed us apply linear $(\mathrm{lm})$ and generalized additive models ( $\mathrm{gam}$ ) to identify spatially congruent phylogeographic breaks among marine species (as areas of high BGF frequency occurrence). $L m$ identified a significant negative correlation between the occurrence of BGF and latitude, suggesting that population in the tropics are genetically more structured than in higher latitudes. This result bears strong association with the latitude species diversity gradient observed worldwide. Gam identified Cape São Roque $\left(05^{\circ} 28^{\prime} \mathrm{S}\right)$ as the main BGF for populations with continuous distribution along the Brazilian coast. Cape São Roque is located near the center point region where the South Equatorial Current splits into the northward North Brazil Current and the southward Brazil Current. This study represents the first literature synthesis of Brazil's marine phylogeography and provides a novel explicit quantitative approach to comparative phylogeography.

\section{Keywords}

Brazil, genetic breaks, gene flow, geographic barriers, marine, phylogeography

\section{Introduction}

Comparative phylogeography is a powerful tool that looks into multiple independent studies to describe broad-scale concordant patterns of population genetic structure across space, taxa and molecular markers (Bowen et al., 2014). Comparative phylogeography also attempts to identify the processes responsible for the development and maintenance of such concordant patterns. The presence of concordant phylogeographic patterns, or spatially congruent phylogeographic breaks among species, often represents shared evolutionary histories across phylogenetically distinct taxa, and hence, identify historical, climatic, geological or ecological forces capable of shaping the evolution of entire biotas (Arbogast \& Kenagy, 2001; Avise, 2000; Dawson, 2013; Hickerson et al., 2010). The search for phylogeographic concordance has become a central objective in comparative phylogeography (Avise, 2000) and results from comparative phylogeographic analyses have major impacts on environment conservation programs worldwide (Olson et al., 2001; Spalding et al., 2007). The presence of a phylogeographic break means that a previous genetically continuous population can now be identified as two, or more, genetically distinct populations. Population genetic differentiation is an essential step towards speciation and can only occur in the absence of gene flow. Historical and vicariance events that interrupt gene flow are termed barriers to gene flow (BGF). Consequently, BGF are intrinsically associated to the formation and maintenance of phylogeographic breaks. Wherever a phylogeographic break occurs, most likely one or more extinct or extant BGF also occurs.

BGF in the marine environment are not easily detected due to the stronger connectivity promoted by watermediated dispersal and the existence in several organisms with larval phases with high dispersal capabilities (Imron, Jeffrey, Hale, Degnan, \& Degnan, 2007). Topographic features such as bluffs, capes, promontories, and peninsulas, together with ocean currents, long stretches of sandy beaches, and the mouth of major rivers have been identified as BGF in coastal marine environments (Bilton, Paula, \& Bishop, 2002; Defeo, 1996; Defeo \& De Alava, 1995; Wares, Gaines, \& Cunningham, 2001). Pleistocene glaciations also represent climatic processes that have played major roles redefining BGF in the marine environment and shaping recent marine biological evolution worldwide. However, glaciation effects on marine biota are better comprehended in the northern hemisphere where its influence was more severe (Guralnick, 2006; Pfenninger, Posada, \& Magnin, 2003; Trewick et al., 2002). In tropical marine habitats, which are areas less influenced by past glaciations, only a few barriers are apparent and most putative BGF remain poorly studied (Rocha, Craig, \& Bowen, 2007).

To date, comparative phylogeography studies and phylogeographic literature reviews include those performed for the USA terrestrial and marine biotas (Shafer, Cullingham, Côté, \& Coltman, 2010; Soltis, Morris, 
McLachlan, Manos, \& Soltis, 2006), the South American terrestrial biota (Turchetto-Zolet, Pinheiro, Salgueiro, \& Palma-Silva, 2013), south Europe terrestrial biota (Feliner, 2011; Taberlet, Fumagalli, Wust-Saucy, \& Cosson, 1998), Australian terrestrial and marine biota (Byrne, 2008; Teske, Sandoval-Castillo, Waters, \& Beheregaray, 2017), and African ungulates (Lorenzen, Heller, \& Siegismund, 2012) and those that targeted a specific group of organisms (e.g. Satler \& Carstens, 2016). No comparative phylogeography analyses or phylogeographic literature reviews have yet focused the Brazilian marine biota. Brazil possesses one of the longest north-south tropical coastlines in the world, with approximately 7,000 km, spanning 37 degrees of latitude (from $4^{\circ}$ North to $33^{\circ}$ South).

The first studies on Brazilian marine phylogeography started in early 90's (Aron \& Solé-Cava, 1991; Russo \& Solé-Cava, 1991) based on allozymes, an extensively used technique in population genetic studies in the previous decades. Aron \& Solé-Cava (1991) did not identify genetic structure in Botryllus niger (an ascidian) populations collected between Espírito Santo and Rio de Janeiro, where Russo \& Solé-Cava (1991) could not detect genetic structure in Bunodosoma caissarum (an anemone) within Rio de Janeiro State. Since then, a large number of articles using different markers, targeting different spatial scales, applying different sampling designs and looking at wide range of phylogenetically distant taxa have been published.

Several putative BGF have been proposed in the literature to explain genetic discontinuities along the Brazilian coast. Chiefly among them, we have: (a) the mouth of major rivers such as the Amazon, São Francisco, Paraguaçu, Jequitinhonha, Doce, and Paraíba do Sul (da Silva, Marceniuk, Sales, \& Araripe, 2016; Machado et al., 2017); (b) the split of the South Equatorial Current (SEC) in two opposing boundary currents, giving rise to the southward Brazil Current and the northward North Brazil Current (Bezerra et al., 2018; Cortinhas et al., 2016); (c) the Cabo Frio coastal upwelling system (Cortinhas et al., 2016; Hurtado et al., 2016) and; (d) the Cassino beach, the longest stretch of sandy beach in the world located in southern Brazil between latitudes $29^{\circ} \mathrm{S}$ and $32^{\circ} \mathrm{S}$ (Nauer, Gurgel, Ayres-Ostrock, Plastino, \& Oliveira, 2019; Trovant et al., 2016). In several phylogeographic studies, genetic discontinuities coincide with these coastal features, allowing researches to identify them as potential BGF (e.g. Hurtado et al., 2016; Lazoski, Gusmão, Boudry, \& Solé-Cava, 2011; Paiva, Mutaquilha, Coutinho, \& Santos, 2019), but sometimes phylogeographic structure does not match such features (e.g. Carmo et al., 2019; Rodrigues et al., 2014; Secchi, Wang, Murray, RochaCampos, \& White, 1998). Extinct BGF could have produced genetic discontinuities that perpetuate over time and can be observed in today's populations, even in the absence of extant BGF. One probable example of such case is the Vitoria-Trindade seamount chain, which geographically includes the Abrolhos Reef system. During Quaternary's glacial maxima, the drop in sea level emerged large eastward inflected areas of the Brazilian continental shelf, including seamounts, splitting the continent's coastline into two sections: (a) a warmer, possibly subtropical, northern bioregion influenced by a weaker Brazil Current; and (b) a colder, probably temperate, southern bioregion influenced by a stronger Malvina's Current (Fig. 1). This BGF has been proposed to explain genetic discontinuities of several marine taxa such as mollusks (Crassostrea spp.: Lazoski et al., 2011), crustaceans (Excirolana braziliensis : Hurtado et al., 2016), polychaetes (Perinereis spp.: Paiva et al., 2019), and red macroalgae (Crassiphycus caudatus : Ayres-Ostrock et al., 2019; Hypnea pseudomusciformis : Nauer et al., 2019).

In the last three decades of cumulative publications on the population genetics and phylogeography of Brazilian's marine species, no literature review or comparative phylogeographic study have been made. Consequently, we still do not know which BGFs, whether one of those listed above or others yet to be revealed, imprinted the largest effect on Brazil's marine biota. Therefore, the objectives of this study were: (a) to provide a comprehensive literature synthesis of Brazil's marine phylogeography; and (b) to perform a comparative phylogeography analysis to identify major BGF along the Brazilian coastline. Comparative phylogeography has traditionally being executed by matching concordant patterns, without explicit quantitative measurements of the degree of concordance (or discordance). This limitation reduces the ability of the discipline to produce predictive models capable to identify new areas of major BGF concordance. This study also provides the first quantitative measure of phylogeographic concordance in the marine environment that allowed us to model and predict the degree to which BGF along the Brazilian coast are responsible for genetic structuring and speciation across multiple taxa. 


\section{Materials and methods}

Literature survey

The database used for this synthesis was compiled from searches in the Web of Science ${ }^{\circledR}$ (Institute of Scientific Information, Thomson Scientific). Web of Science is an online academic database from ISI Web of Knowledge ${ }^{\circledR}$ that provides access to information about indexed research journals worldwide. We searched all Web of Science databases for scientific articles published from 1987 (regarded as the birth of phylogeography; Avise, 1987) to 2019 using the following keywords and Boolean command combinations: population* genetic* OR phylogeo*; AND Brazil*; AND ocean* OR sea* OR island OR reef OR rocky shore OR benthic OR marine OR coast*. Preliminary results identified 1380 articles, several of them outside the target parameters. Thus, we used the following secondary filters to further sort phylogeographic articles addressing specifically marine species that occur in Brazil: NOT "Atlantic forest" OR rainforest* OR freshwater. After applying secondary filters, 1170 articles remained.

A third-level filtering was performed by hand, visually scanning each article (i.e. title, abstract, hypotheses, material and methods, or results), and excluding those with the following characteristics: review articles; conference abstracts; technique articles; articles that studied viruses and bacteria (marine or otherwise) and human diseases; articles that presented only one sampled population in Brazil; articles that were purely taxonomic; articles that involved only populations located in offshore oceanic islands (i.e. São Pedro - São Paulo Archipelago, Trindade seamount chain Island, Rocas Atoll, Fernando de Noronha Archipelago, and Rio Grande seamount); articles that involved non-native Brazilian marine species; articles that despite claiming they implemented phylogeographic analyses, did not use molecular data to test for the presence of phylogeographic structure among populations; and articles addressing taxa that live in close proximity to the marine environment but do not depend in any way of the marine ecosystems to exist. Thus, this study focused on empirical, molecular data-driven phylogeographic articles that minimally addressed the Brazilian's continental coastline and native marine biota, including marine birds and plant mangrove species.

All selected articles were fully read. A database was built based on information extracted from the articles and included: year of publication; species taxonomy assigned to 16 categories (Ascidiacea, Aves, Cetacea, Cnidaria, Crustacea, Echinodermata, Fishes, Kinorhynch, Mollusca, Nemertea, Otariidae, Plantae, Platyhelminthes, Polychaeta, Porifera, and Testudinata); number of analyzed taxa per article; sample site locations (city, state and geopolitical zone name, coordinates); genetic markers used (technique, genome and name of used genes); presence or absence and number of genetic discontinuities reported, locations from where genetic discontinuities were reported; classifications of species habitat (as benthic, pelagic, or aerial) and functional forms (invertebrates, vertebrates, or plants). Basic statistics were calculated from this database using Microsoft Excel tools.

In this study we refer to article $(s)$ each and every publication or unique reference, and we refer to 'study (-ies )' each species with phylogeographic information found within each article. Therefore, some articles were comprised of only one study, while multi-taxon articles contained two or more studies (taxa).

Dataset preparation

A data matrix comprised by all sample sites reported in allstudies was built from the database described above. For each study captured in our database, sites where sampled populations occurred were logged in the data matrix as 0's. Sites located between sampled populations where genetic discontinuities were recorded, and hence putative BGF existed, were logged as 1's. Thus, for each study, whenever panmixia were detected, geographic ranges between genetically homogeneous populations were marked as a string of zeros between sample sites. From this data matrix, we built a frequency data matrix by summing all putative BGF occurrences across logged studies, normalized by the total number of studies that included each site (Table $\mathrm{S} 1)$.

A large normalized BGF frequency value in a given site indicates that a large number of studies identified that particular site as either a BGF or a location of high probability of occurrence of BGF. Consequently, 
those sites can be considered locations of high BGF concordance. Conversely, a small value means either absence of BGF in a particular site (= area of high genetic connectivity) or that a small number of articles and studies included those sites within the range of their sampling designs. A distribution of the frequencies of occurrence of putative BGF along a latitudinal gradient (which is the case for most of the Brazilian coast) can be easily applied to comparative phylogeography, because this distribution represents the likelihood for which a phylogeographic break exists in a given location given by multiple empirical studies. Thus, the frequency of occurrence of putative BGF not only quantifies but also describes how one of the most important concepts in comparative phylogeography is distributed in space: concordance in the spatial distribution of phylogenetic breaks across co-occurring species (type III concordance in Avise, 2000).

Modelling

For modeling analyses, we used the normalized BGF frequency dataset described above. Due to the smaller number of studies and hence larger numbers of missing data from sampling sites at Brazil's northernmost and southernmost locations, those sites were excluded from the analysis. The resulting spatial range included in the models varied between central Pará (Belém: 01 24' S 48 29' W) and south of Rio Grande do Sul (Patos lagoon inlet: $31^{\circ} 22^{\prime} \mathrm{S}$ ). This encompassed 201 of the 211 sites included in the original dataset. A general linear model $(l m)$ was initially used to test for the presence of significant non-random differences in the frequency distribution of BGF concordances across latitudes along the Brazilian coast. We used the $g l m$ function available in the package stats implemented in R (R Core Team, 2020) with the default parameters. Initial data exploration showed that the response of frequency distribution of BGF concordances to latitude was non-linear. Then, generalized additive modelling $(\mathrm{gam})$ was used with latitude as a smooth effect. First, we modelled all data combined and then individually each taxa with the greatest number of available data (fishes, crustaceans, mollusks and cnidarians). We used the gam subroutine available in the mgcv package (Wood, 2017) implemented in R. We fitted the gam 's using Gaussian distributions including for logistic regression. We also used a smooth term with a cubic regression or cyclic cubic regression spline (for fishes and crustacean data) to represent latitudinal variation. Severalgam models were tested varying the smooth terms parameters: $f x$ (fix the degrees of freedom on a regression spline model), the $K$ (dimension of the basis used to represent the smooth term) and the $b s$ (smoothing term) parameters. The optimal model was selected using the gam.check tool (Wood, 2017). Model validation was assessed using the generalized cross-validation (GCV) index, the Unbiased Risk Estimation (UBRE), the "starry-sky" patterns in the residuals versus linear prediction graph, and a the linear relationship between response parameter and the fitted graph. The Effective Degree of Freedom (EDF) was used to test if gam was a valid method to analyze our datasets (i.e. EDF > 2). Model quality was also assessed by comparing adjusted $\mathrm{R}^{2}$ and the explained deviance.

Differences between average values of BGF frequencies among phylogeographyc regions identified in the gam results were using analysis of variance (ANOVA) with type-3 sum of squares. Normality and homogeneity assumptions of variances were tested using Shapiro-Wilk and modified robust Brown-Forsythe Levene-type test, respectively (Zar, 1999). Tuckey was used as the post hoc test. Analyses were done in R (R Core Team, 2020) using aov function in car package, and adopting an alpha of 0.05.

\section{Results}

\section{Literature survey}

The final number of articles was 159, representing 195 studies, covering 211 sites. The northern and southernmost sampling locations were Oiapoque (latitude: $4^{\circ} \mathrm{N}$ ) and Chuí (latitude: $34^{\circ} \mathrm{S}$ ), respectively, spreading across $\sim 7,000 \mathrm{~km}$, representing nearly the entire Brazilian coast. Articles comprised of only one study represented $80 \%$ of the total, followed by articles composed by two (11\%), three (6\%), and four (2\%) studies. Only one article presented 6 studies of which only 3 were used based on the second-level filtering criteria listed above (Nunes, Norris, \& Knowlton, 2011). The oldest articles were published in 1991 (two articles) and the newest in 2019 (12 articles). Since 1991 the number of publications per year increased, particularly after the year 2001 (four articles/year) when a steady increase is noticed, culminating in the publication of at least 10 articles per year after 2014 (Fig. 2). The five journals with the highest number of articles were 
listed in Table 1.

Markers

Ten different molecular techniques were reported in the literarure: allozymes, DNA sequencing, ddRAD, RAPD, ISSR, AFLP and RFLP, cariology, SNP and microsatellites (Fig. 3A). DNA sequences obtained via automated Sanger sequencing were the most commonly used type of molecular data ( $71 \%$ studies). Among DNA sequence markers, a total of 38 different genes were used; 16, 19 and 3 encoded in the mitochondrial, nuclear and chloroplast genomes, respectively. DNA sequencing of mitochondrial genes was by far the most used technique among all markers and across all studies (80\%), followed by the DNA sequencing of nuclear $(18 \%)$ and chloroplast-encoded markers $(2 \%)$. Within the mitochondrial genome, the D-loop region and the COI DNA barcode marker were the most used marker (34\% each), followed by the cytochrome B gene (15\%). The number of articles using microsatellites or allozymes were similar (12\% and $10 \%$, respectively). The first allozyme study was published in 1991 (Aron \& Solé-Cava, 1991; Russo \& Solé-Cava, 1991) and the last in 2018 (Pazoto, Ventura, Duarte, \& Silva, 2018). Only four articles (6\%) targeted autotrophic organisms, two terrestrial vascular plants (mangroves) and two red macroalgae, and two of them used chloroplast-encoded markers (Ayres-Ostrock et al., 2019; Mori, Zucchi, Sampaio, \& Souza, 2015). Only one more recent article used the SNP technique (Siccha-Ramirez et al., 2018).

Geographic coverage, taxonomic coverage, habitats diversity \& functional forms

Brazil has 17 geopolitical states along its coastline and they were all included in this synthesis (Table 2). The geopolitical state with the largest number of articles reporting at least one sample site inside its borders was the Rio de Janeiro (48\%, 93 studies), followed by São Paulo (46\%, 89 studies) and Bahia (44\%, 86 studies). The least sampled states were Piauí (4\%, eight studies), Sergipe and Amapá (6\%, 12 studies). Only 16 high-ranked taxonomic groups were identified in all articles (Fig. 3B). The state with the largest number of studied taxa was São Paulo with 14 taxa followed by Rio de Janeiro (13 taxa) and Santa Catarina (12 taxa). The states with the smallest number of sampled taxa were Amapá and Alagoas with only 4 taxa each (Table 2).

Three taxa presented sample sites located within only one state: otaries (Rio Grande do Sul: Artico et al., 2010), echinoderms (Rio de Janeiro: Calderón, Ventura, Turon, \& Lessios, 2010; Duarte, Ventura, \& Silva, 2016; Pazoto et al., 2018; Wangensteen, Turon, Pérez-Portela, \& Palacín, 2012), and Kinorhynchs (São Paulo: Randsø, Domenico, Herranz, Lorenzen, \& Sørensen, 2018). Together with flatworms (= Platyhelminthes, Marigo et al., 2015), phylogeographic studies targeting these taxa concentrated their sampling in the southern Brazil $\left(>21^{\circ} \mathrm{S}\right)$. Fishes and mollusks presented the most comprehensive and spatially widespread sampling across Brazil (100\% states), followed by crustacean (16/17 states), and plants (14/17 states). Fishes were the most studied taxon encompassing $32 \%$ of all studies, followed by crustaceans (21\%) and mollusks (10\%) (Fig. 3B). Of all studied taxa, $49 \%$ were invertebrates, followed by $47 \%$ of vertebrates, and $4 \%$ plants, including algae (Fig. 3C). Regarding habitat, $63 \%$ studies targeted benthic species, $34 \%$ pelagic, and $3 \%$ aerial (i.e. coastal and marine birds) (Fig. 3D).

Models

The site with the highest value of BGF concordance was Galinhos $\left(05^{\circ} 03^{\prime} \mathrm{S}, 36^{\circ} 45^{\prime} \mathrm{W}\right)$; north of Rio Grande do Norte State $(27 \%)$. The linear model identified a statistically significant negative relationship between frequency in the occurrence of phylogenetic breaks (BGF) and latitude, $\mathrm{R}^{2}=0.4, \mathrm{p}<0.001$ (Fig. 4). Gam results from all data combined (= total analysis) identified four geographic regions with distinct patterns of BGF frequency distribution along the Brazilian coast, herein dubbed phylogeographic Regions I-IV (Fig. 5). Anova detected significant differences in the average amount of BGF frequencies among these regions. Pairwise tests found no differences between Regions I and II but Regions III and IV where different from all the others (Fig. 6). Gam Region I $\left(0^{\circ} \mathrm{S}-10^{\circ} \mathrm{S}\right)$ was located in northern Brazil and presented a bellshaped BGF frequency distribution with the greatest modelled values of BGF concordance in the entire Brazilian coast. Gam identified Natal city in central Rio Grande do Norte $\left(05^{\circ} 46^{\prime} \mathrm{S}\right)$ as the region with the highest value of BGF concordance (Fig. 5). Region II showed a relative homogenous distribution of BGF 
concordances south of $10^{\circ} \mathrm{S}$ until the Vitória-Trindade seamount chain region at $20.5^{\circ} \mathrm{S}$. Region III $\left(20.5^{\circ}\right.$ $\mathrm{S}-27^{\circ} \mathrm{S}$ ) exhibited an inverted bell-shaped distribution with the lowest BGF concordance values, ranging from central Espírito Santo to northern Santa Catarina (Itajaí: 26 $54^{\prime}$ S). Region IV was characterized by a moderate bell-shaped distribution of BGF concordance values that started at northern Santa Catarina and extended to the north-end of longest uninterrupted sandy seashore in the world (Patos lagoon inlet: $31^{\circ} 22^{\prime}$ S). In Region IV the gam maximum BGF concordance value occurs in southern Santa Catarina, Cape Santa Marta, $28^{\circ} 36^{\prime}$ S (Fig. 5).

Gam for the four most studied taxa (fishes, crustaceans, mollusks, and cnidarians) produced patterns of BGF frequency distribution similar to those reported in the total analysis, although slightly differences were noted (Figs. 7A-D). Fishes, the most data-rich taxon (Fig. 7A), presented the I-IV region pattern reported in the total analysis but the main peak of maxima was observed at the southern-end of Region II, around central Rio de Janeiro (Saquarema: $22^{\circ} 56 \mathrm{~S}, 42^{\circ} 29 \mathrm{~W}$ ), followed by a slightly lower maxima in Region I. Latitudes or a string of adjacent sites with values of BGF frequency distribution equal to $0 \%$ identifies regions of widespread panmixia, and that was the case for fish populations sampled between Paraná (Laranjeiras Bay: $25^{\circ} 24^{\prime} \mathrm{S}$ ) and northern Santa Catarina (Itajaí: $26^{\circ} 54^{\prime} \mathrm{S}$ ). A thirst albeit small maxima was also observed inside Region II, coinciding with central Bahia state (Barra Grande: 13 52' S). Accordingly, fishes' gampresented four regions of BGF frequency maxima: northern Rio Grande do Norte (around Galinhos: $05^{\circ}$ $03^{\prime} \mathrm{S}, 36^{\circ} 45^{\prime} \mathrm{W}$ ), central Bahia (around Barra Grande: $13^{\circ} 52^{\prime} \mathrm{S}$ ), central Rio de Janeiro (around Saquarema: $22^{\circ} 56 \mathrm{~S}, 42^{\circ} 29 \mathrm{~W}$ ), and southern Rio Grande do Sul (near Patos lagoon inlet: $31^{\circ} 22^{\prime} \mathrm{S}$ ) (Fig. 7A).

Even though the crustacean gam presented similar topology to those obtained from the other three taxa and the total evidencegam, this taxon showed slightly unique pattern of BGF frequency distribution (Fig. 7B). The greatest modelled BGF frequency value for crustaceans along the Brazilian coast occurred near Cape Santa Marta, 28 36' S (23\%), in phylogeographic Region IV. The north and northeastern Brazilian coast showed a somewhat homogenous BGF frequency distribution ranging from Pará (Belém: 01 24' S), to south Espírito Santo (Guarapari: 20 40' S) (Fig. 7B). An increase in the values of crustacean BGF frequency, denoting a bell-shape topology, was observed in southeastern Brazil, starting in Guarapari (Espírito Santo), peaking at central Rio de Janeiro (within the Cabo Frio district, $22^{\circ} 57^{\prime} \mathrm{S}$ ) and ending in northern São Paulo (Ubatuba: $23^{\circ} 26^{\prime}$ S) (Fig. 7B). A long region of lower BGF frequencies (similar total dataset Region III) occurred south of Ubatuba (São Paulo) and extended to north Santa Catarina (Itajaí: $26^{\circ} 54^{\prime}$ S).

For mollusks and cnidarians, recorded BGF values in the literature are absent west of Belém $\left(01^{\circ} 27^{\prime} \mathrm{S}, 48^{\circ}\right.$ $29^{\prime} \mathrm{W}$ ) and Fortaleza ( $\left.03^{\circ} 43^{\prime} \mathrm{S}, 38^{\circ} 31^{\prime} \mathrm{W}\right)$, respectively, and south of Florianópolis $\left(27^{\circ} 36^{\prime} \mathrm{S}\right)$ for both groups (Figs. 7C and 7D). Gam results for mollusks and cnidarians presented several similarities. Mollusks and cnidarians showed the greatest values of BGF frequency distribution in their northernmost latitudes within Brazil (phylogeography Region I in the total evidence gam ), with maximum values reaching 50\% and $75 \%$, respectively. For mollusks, the maximum BGF concordance occurred around west of Fortaleza at Ceará state, all the way to Maranhão state (Fig. 7C). For cnidarians, the region of maximum BGF frequency values occurred north of João Pessoa, Paraíba (Fig. 7D). Mollusks presented an average of $21 \%$ of BGF concordances spread across a large portion of the Brazilian coast, from latitude $04^{\circ} 50^{\prime} \mathrm{S}$ to $25^{\circ} 24^{\prime} \mathrm{S}$, corresponding to Region II in the total dataset results (Fig. 5). Cnidarians also presented a Region II-like distribution between latitudes $10^{\circ} \mathrm{S}$ and $20^{\circ} \mathrm{S}$. Interestingly, results from all four taxa showed a region of BGF gam minima (Figs. 5A-D) that tends to coincided with the minima observed in the total evidence gam between latitudes $20^{\circ} \mathrm{S}$ and $25^{\circ} \mathrm{S}$ (= Region III in Fig. 5). This region of BGF frequency minima was always followed by an increase in BGF frequency farther south (Region IV), passing $25^{\circ} \mathrm{S}$ latitude and generally peaking at Cape Santa Marta (28 $36^{\prime}$ S).

\section{Discussion}

\section{Literature synthesis}

Phylogeography was conceived as a science in 1987, since then the number of publications has grown exponentially. In Brazil, the first two marine phylogeographic studies were both published in 1991 using allozymes 
(Aron \& Solé-Cava, 1991; Russo \& Solé-Cava, 1991). New publications have increased ever since. The years 2016 and 2018 presented the highest number of Brazilian marine phylogeographic publications to date (15 articles). Considering the 16 taxonomic groups assessed in this study, fishes have been the most studied taxon, accounting for $33 \%$ of all publications. This is more than the second and third most studied taxa combined (crustaceans 21\%, mollusks 9\%). A conspicuous publication bias towards fish phylogeographic studies is observed in the literature globally. Beheregaray (2008) reviewed all phylogeographic articles published between 1987 and 2006 and fishes were ranked second, after mammals, as the taxonomic group with the largest number of publications without much difference whether they were freshwater (45\%) or marine species (55\%). Turchetto-Zolet et al. (2013) reviewed all phylogeographic articles published on South America terrestrial and freshwater biota between 1987-2011 and reported fishes as the second ranked taxonomic group (13\%) together with overall invertebrates and second only to plants (17\%). This bias towards fishes is probably due to their economic importance as human food and ecotourism, relative easier taxonomic identification, simple life-cycle and ploidy, the availability of well-suited genetic markers, and probably, the existence of a large number of hired expertise in research institutions. Differently, otaries, Kinorhynchs and flatworms presented very localized sampling due to low number of publications (one each).

The numbers of marine vertebrate and invertebrate studies in Brazil were quite even, $47 \%$ and $49 \%$, respectively. This is opposite to what was recorded by Beheregaray (2008) and Turchetto-Zolet et al. (2013) who observed a bias towards vertebrate studies, $57 \%$ and $70 \%$ respectively. The number of marine plants and algae studies in Brazil were quite underrepresented (4\%) as they are in terrestrial and freshwater autotrophic species in South America (1\% algae in Turchetto-Zolet et al., 2013), terrestrial and marine plants in eastern North America (11\% in Soltis et al., 2006) and world widely in general (2\% reported in Beheregaray 2008). In the past, the disparity between the number of phylogeographic studies between heterotrophic $\mathrm{x}$ autotrophic species was attributed in part to the faster mutation rates observed in animal markers (mitochondrial genome) compared to markers available for plant studies (Soltis et al., 2006). An increase in the number of studies addressing macroalgal phylogeography would improve our understating of population genetic histories and marine phylogeography considering they are poorly-dispersers (Kinlan \& Gaines, 2003), potentially being able to identify a larger number of local and regional BGF and concordant phylogeographic patterns.

The first study using genotypic data addressing the phylogeography of a Brazilian marine species was published in 1998 (Secchi et al., 1998), 11 years after the Avise's seminal 1987 publication. Before 1998, the only six phylogeographic studies (= four articles) addressing Brazilian marine biota used phenotypic (isozyme) data. In Brazil mitochondrial genotypic data started being utilized first in the form of fragment-based methods (e.g. Secchi et al., 1998). Between 2007-2010, RAPD, AFLP, RFLP and similar fragment-based techniques played an important role increasing the number of publications. Microsatellites remain a poorly used technique with only 29 studies (12\%) published since 2001 (Beheregaray \& Sunnucks, 2001). A similar pattern was observed for genome-wide techniques, such as SNPs, where only one marine study was published to date (Siccha-Ramirez et al., 2018). In the world, genome wide SNP and high-throughput DNA sequencing techniques are becoming the powerhouse in phylogeographic studies (e.g. ddRadseq, B. Peterson, Weber, Kay, Fisher, \& Hoekstra, 2012).

The two most well sampled and phylogeographically well studied geopolitical states were Rio de Janeiro and São Paulo, which happens to be the two richest states and the ones that hold the largest number of research universities in the country, followed by Bahia (the state with the longest coastline). The relationship between number of phylogeographic studies and economic affluence is a well-known worldwide pattern in the phylogeographic literature (reported in Beheregaray, 2008; Turchetto-Zolet et al., 2013). The weaker studied regions of Brazil are those located in the extreme northern and southern reaches of the country, where physical accessibility is challenging. Particularly the northernmost reaches, along the Amazonian Rainforest coastline towards Amapá, west of Belém ( $48^{\circ} 29^{\prime} 25^{\prime \prime} \mathrm{W}$ ) where nearly nothing is known about the phylogeographic structure of any coastal marine species. The mouth of the Amazon river is considered a strong BGF in coastal South America but studies that attributed it to explain genetic discontinuities used populations samples thousands of kilometers apart across the western Atlantic Ocean (e.g. Caribbean versus Brazilian population (see de Souza et al., 2015; Nauer et al., 2019; Santos, Hrbek, Farias, Schneider, 
\& Sampaio, 2006).

Linear model

The $l m$ identified a significant latitudinal gradient in BGF frequency distribution along the Brazilian coast. A significant negative correlation between BGF frequency and latitude was observed. The number of BGF within a given region, represented here as the frequency of putative BGF concordances across multiple taxa and markers per site, tend to decrease as latitude increases. This result concurs with one of the most ubiquitous large-scale biotic pattern on Earth, thelatitudinal gradient in species diversity (LGD). Several hypotheses have been proposed and a plethora of papers, text books and reviews have been published, to explain the causes of LGD

(e.g. Fine, 2015; Pianka, 1966; Stevens, 1989). To make matters more complicated, our latitude BGF gradient can be both, a result of particular drivers used to explain LGD (e.g. climate stability, available energy, temperature, body size, metabolic rate) and as a driver itself (confounded with other hypotheses such as the 'higher spatial heterogeneity' hypothesis, Pianka, 1966). As a driver, all other factors being equal, our "BGF concentration hypothesis" predict that a greater number of BGF in a particular location would inevitably drive higher species diversity across evolutionary time.

Jablonski, Huang, Roy, \& Valentine (2017) over-simplistically classified LGD hypotheses into two nonmutually exclusive categories:in situ hypotheses (also known as the 'producer hypothesis') and spatial dynamics hypotheses (also known as the 'receiver hypothesis') (se also Stebbins, 1974). The former category suggests that causes for higher species diversity in lower latitudes are driven by local environmental factors driving higher speciation. The latter category suggests that higher species diversity in the tropics is driven by the arrival and concentration of species arising elsewhere (e.g. temperate regions). Our results support the theory that speciation rates are higher at lower latitudes not only due to factors related to species' intrinsic biology such as smaller body size, faster metabolic rates and shorter life cycles (Fine, 2015) but also due to the occurrence of higher frequency of BGF in lower latitudes - an in situhypothesis. According to our data, higher BGF frequency in lower latitudes tend to produce more genetically structured populations, which in due time give rise to different species locally. Additionally, our results also help identify one of the processes driving Rapoport's rule, that species latitudinal ranges are usually smaller at lower latitudes than at higher latitudes. Smaller latitudinal ranges between species, particularly between sister-species and within species complexes, at lower latitudes can be the result of higher frequency in BGF occurring within smaller spatial scales.

We call the reader's attention to the fact that worldwide patterns of LGD are a result of several millions of years of evolution and most of the phylogeographic data used in this study was shaped in far smaller time scales ([?] 2 million years). The extent at which higher frequency of BGF at lower latitudes is either a recent, localized, phenomenon (i.e. Brazil-centric) or a universal evolutionary process helping drive LGD in the planet remains to be determined. However, marine and terrestrial fossil records (Mittelbach et al., 2007) and, more recently, large scale phylogenetic studies (Jablonski et al., 2017; Verbruggen et al., 2009) suggest that higher speciation rates in lower latitudes has occurred across geological time, worldwide.

Generalized additive model

The strongest marine BGF and hence the location of maximum phylogeographic concordant genetic discontinuities along the Brazilian coast was Natal, at central Rio Grande do Norte. Natal, is located $51 \mathrm{~km}$ south of Cape Sao Roque, the easternmost promontory of the South American continent, and the region where the South American continent turns southward at 05deg S latitude. Cape Sao Roque is also where the broad offshore SEC end up bifurcating into two nearshore boundary currents, the northward North Brazil Current and the southward Brazil Current (Molinari, 1983; R. Peterson \& Stramma, 1991). Most likely, this largest BGF concordance along the Brazilian coast is related to the bifurcation of the SEC at this region of the coast. The split of nearshore boundary currents has been recognized as a common vicariant biogeographic process promoting genetic discontinuities in continuously distributed marine species, including species with high dispersal capabilities (Avise, 2000). Examples include the oyster Crassostera virginica and the red alga 
Gracilaria tikvahiae distributed north and south of Cape Canaveral where the northward Gulf Stream is deflected offshore and southward costal currents arrive from northern latitudes (Gurgel, Fredencq, \& Norris, 2004; Reeb \& Avise, 1990). Phylogeographic Region I is also recognized as the region with overall larger values in the frequency of BGF concordances for other sites along the Brazilian coast. This region is characterized by a tropical climate, with wet winters and dry summers, strong coastal winds, nearshore sedimentary reefs and higher tidal amplitudes compared to the other regions of Brazil's coastline. Most of the SEC flows into the strong North Brazil Current and hence offshore transport within this current is considered higher (R. Peterson \& Stramma, 1991).

The flow in opposite directions of the two Brazilian boundary currents was first proposed as a BGF in the phylogeographical study of the crustacean Micropogonias furnieri (Puchnick-Legat \& Levy, 2006). Since then several other studies have tested and detected BGF at this region, including another crustacean (Panulirus argus: Diniz, Maclean, Ogawa, Cintra, \& Bentzen, 2005), six fish species (Bezerra et al., 2018; Cortinhas et al., 2016; da Silva et al., 2016; Mendonca, Oliveira, Gadig, \& Foresti, 2011; Montes et al., 2018; Santos et al., 2006), some plant species (Rhizophora spp.: Francisco, Mori, Alves, Tambarussi, \& de Souza, 2018; Pil et al., 2011), and a turtle species (Eretmochelys imbricata: Proietti et al., 2014). Our results therefore identify the split of the SEC as the main process driving producing the greatest pattern of BGF overall concordance along the Brazilian coast, answering one of the main questions in this study.

Phylogeographic Region II (10deg S - 20.5deg S) represents the coastline influenced by the first half of the Brazil Current. The transport of the Brazil Current, and hence its connectivity capabilities, is weak throughout its southward flow compared to other boundary currents because most of the water mass from the SEC is diverted northward into the North Brazil Current (R. Peterson \& Stramma, 1991). Within Region II coastal counter-currents and other historical, geographical, climatic, estuarine and oceanographic processes play important roles driving marine larval dispersal and genetic connectivity (da Silva et al., 2016; Imron et al., 2007; Pil et al., 2011). Region II, presents a relative constant value in the frequency of potential BGF occurrences averaging at 19\% from Ipoiuca (8deg 33' S) to the Abrolhos Reef Basin and the Vitoria-Trindade seamount chain at latitude 20.5deg S. BGF within this region are considered weak, porous, intermittent or species-specific, with strong influence on the distribution of several marine organisms (da Silva et al., 2016). Along this coastline, potential BGF are traditionally associated with the mouth of large rivers such as the Sao Francisco, the Paraguacu, and the Doce. River-associated vicariance in Brazil was first proposed for terrestrial lizards (Pellegrino et al., 2005) and then observed for others marine taxa, such as the mollusks Anomalocardia brasiliana (Arruda, Beasley, Vallinoto, Marques-Silva, \& Tagliaro, 2009) and the fish Rhizoprionodon porosus (Mendonca et al., 2011). The outflow sediment plume of the Sao Francisco river might act as a BGF for some organisms. In addition, the turbidity and low salinity caused by freshwater discharge inhibits the development of coral reefs at Sergipe and Alagoas, which could also act as another BGF to a range of benthic reef species. The absence of reefs allows the tide to penetrate local estuaries, contributing to the establishment of mangroves, changing the coastal ecosystem (da Silva et al., 2016) and creating potential BGF. Therefore, the combination of these three factors might be acting differently in different species and places within Region II.

Between latitudes $16 \mathrm{deg}$ and $20.5 \mathrm{deg} \mathrm{S}$, the continental shelf becomes shallower and wider to form the Abrolhos Archipelago Basin and eastward Vitoria-Trindade seamount chain. This region splits the Brazilian coastline into two sections, especially during past periods Quaternary's glacial maxima, when the sea level was $110 \mathrm{~m}$ lower than the present day (R. Peterson \& Stramma, 1991; Stramma \& England, 1999). The emersion of wider offshore reefs and islands areas in the Abrolhos Arquipelago and the tops of VitoriaTrindade seamount chain caused strong changes in the flow of the Southern Brazil Current, restricting gene flow along the Brazilian coastline. In addition, during glaciations, the Subtropical Convergence could also act as a barrier, when occurring near Vitoria-Trindade seamount chain (20.5deg S) (R. Peterson \& Stramma, 1991; Stramma \& England, 1999), which is currently located in southern Brazil and Uruguay (R. Peterson \& Stramma, 1991). The interaction between the Abrolhos Basin, The Vitoria-Trindade seamount and the changes in oceanic connectivity during glacial maxima have been suggested as major extant barriers of gene flow for several organisms, such as mollusks (Crassostrea spp.: Lazoski et al., 2011), crustaceans 
(Excirolana braziliensis : Hurtado et al., 2016) and polychaete (Perinereis spp.: Paiva et al., 2019). The genetic discontinuities between populations sampled north and south of the Abrolhos Basin and the VitoriaTrindade seamount region most likely originated in the Pleistocene and remained structured to this day, even after the barrier is no longer active.

Region III (20.5deg - 27deg S latitude) ranges from the Vitoria-Trindade seamount chain to Santa Catarina representing a region with the lowest levels of BGF occurrence. Populations in this area tend to retain new mutations and low genetic diversity, which is a signature of sudden population expansion (Grant \& Bowen, 1998). Several studies reports this particular genetic pattern in the region such as fish species (da Silva et al., 2016; Machado et al., 2017; Santos et al., 2006), macroalgae species (Crassiphycus caudatus: Ayres-Ostrock et al., 2019; Hypnea pseudomusciformis : Nauer et al., 2019), marine vascular plants (Rhizophora spp.: Francisco et al., 2018), a cnidarian (Mussismilia hispida : Peluso et al., 2018), nemerteans (Ototyphlonemertes spp.: Andrade, Norenburg, \& Solferini, 2011), polychaetes (Perinereis spp.:Paiva et al., 2019), and a sea turtle (Caretta caretta : Reis et al., 2010). Sympatric tropical marine species undergoing sudden population expansion reflects a shared past history of generalized low effective population sizes caused by bottlenecks or founder events. This concordance is most likely the result of demographic expansion of tropical populations within Region III promoted by the gradual warming since the last glacial maxima. This region is, therefore, an area of relative smaller number of BGF and higher panmixia. We found only three studies with opposite results to this pattern: two fish studies (Galeocerdo cuvier : Carmo et al., 2019; Macrodon atricauda : Rodrigues et al., 2014), and a dolphin study (Pontoporia blainvillei : Secchi et al., 1998). These three species also share the fact that higher genetic diversity was detected in populations located south of the Vitoria-Trindade seamount chain compared to populations sampled north of this region and their geographic distribution extends into the temperate zone, towards Uruguay and northern Argentina. Hence, they are not exclusively tropical species.

The Cabo Frio seasonal upwelling system in the north of the Rio de Janeiro (around 22deg S) (Valentin, Andre, \& Jacob, 1987) has been considered a popular BGF hypothesis for coastal benthic marine species (Peluso et al., 2018). The upwelling occurs with great intensity during austral summer. It is a consequence of seasonal northeast winds, abrupt change in the continental shelf shape and slope, resulting in the upwelling of the South Atlantic Central Water (Valentin et al., 1987). The Cabo Frio upwelling system could act as a barrier to gene flow in two ways: a) physical/physiological barriers due to conspicuous shifts in sea temperatures, or b) local selection limiting recruitment of certain genotypes (Peluso et al., 2018). We detected the presence of a weak sign of phylogeographic concordance in this region, however only a few studies support the existence of a BGF in this area. Studies that identified the Cabo Frio upwelling system as a BGF include a fish species (Atherinella brasiliensis : Cortinhas et al., 2016), crustaceans (Excirolana braziliensis : Hurtado et al., 2016; Litopenaeus schmitti : Maggioni, Rogers, \& Maclean, 2003), and a cetacean (Tursiops truncatus : de Oliveira et al., 2019). The upwelling system might be acting more as a genetic filter rather than a barrier to the majority of marine organisms (Peluso et al., 2018).

The lowest values of BGF frequency observed in Region III coincides with poorly studies areas between southern Sao Paulo state and northern Santa Catarina State. This is a poorly sampled region due to the lack of urbanization in the area. It is also characterized by sandy beaches, smaller and shallow rocky shores, and two large estuaries, the Paranagua bay and the Guaratuba estuary. Interestingly, the two lowest BGF frequency values observed in this study matched precisely these two estuaries, $6.94 \%$ and $7.25 \%$, respectively. Large estuaries are expected to act as BGF because they often disrupts coastal marine environmental conditions by dumping large quantities of freshwater, nutrients, sediments, influencing tides and coastal currents. Instead, our results suggest that these two estuaries promote genetic connectivity among costal marine populations.

Low levels of BGF frequency in Region III is interrupted at south Santa Catarina state and northern Rio Grande do Sul frontier and highlights the beginning of phylogeographic Region IV. Region IV has several consecutive estuaries intercalated with open sea areas, which could be acting as BGF, specially to fish species (Beheregaray \& Levy, 2000; Rodrigues et al., 2014), cetaceans (Costa et al., 2015; Fruet et al., 2014; Secchi 
et al., 1998), and crustaceans (Weber \& Levy, 2000). Geographically close estuaries could be very different from each other, in salinity, temperature, water quality and food stocks. Thus, populations can use different estuaries for either reproduction or foraging. Therefore, geographically close populations using different estuaries could present genetic discontinuity due to differences in estuaries usage (Weber \& Levy, 2000). In addition, the observed differentiation could be related to the subtropical confluence of the warm saline, Brazil Current, and the cold, northerly Malvinas' current (R. Peterson \& Stramma, 1991). The northern limit of this confluence moves seasonally from $30-35 \operatorname{deg} \mathrm{S}$ during the winter to 40deg S - 46deg S during the summer (R. Peterson \& Stramma, 1991). This oceanographic processes has been proposed a BGF (Cortinhas et al., 2016; Vasconcellos, Lima, Bonhomme, Vianna, \& Sole-Cava, 2015). Lastly, this region also coincides with the north end of the Rio Grande do Sul state, a region that include the world's longest beach, Cassino beach, with 220 kilometers of unconsolidated sandy substratum. Long stretches of sandy beaches have been considered putative BGF for hard bottom marine species (Nauer et al., 2019; Trovant et al., 2016). However, we could not test if Cassino beach can be considered a BGF because this region is located at the geographic extreme of our study area. This region encompasses the Cape Santa Marta which might act (or might have acted) as a BGF by deflecting the Malvina's Current offshore (R. Peterson \& Stramma, 1991). Capes are often regarded as BGF, e.g. Cape Canaveral (Gurgel et al., 2004; Reeb \& Avise, 1990), by deflecting coastal boundary current offshore.

The SEC split and Vitoria-Trindade seamount chain represent more noticeable BGF for fishes than any other taxa. An intermediate BGF at northern Rio Grande do Sul state also occurs. For crustacean data, the SEC split is not a major BGF, as observed for other taxa. The main crustacean BGF occurs at the northern Rio Grande do Sul state. For mollusks data, only the SEC split seems to be the main BGF concordance, acting as a barrier to almost $50 \%$ of the studied mollusk taxa, followed by plateau from Sao Francisco river mouth and the region of lowest BGF registered in this study, within Region III. For the cnidarian data, there is a strong BGF at northernmost sampled zone and two secondary peaks: one at Abrolhos (southern Bahia state) and another in Santos city (Sao Paulo). However, the cnidarians data should be interpreted with care, considering the low number of studies $(\mathrm{n}>5)$.

Concluding remarks

Phylogeographic studies of the Brazilian coast is still in its infancy when comparing to others biomes and areas of the world. To date, no phylogeographic review have been conducted focusing on Brazilian marine organisms. This study aimed to compile and better understand which and how major oceanographic and geographic processes found along the Brazilian coast could be acting as BGF. Amongst the recurrent geographic features, the split of the Southern Equatorial Current in two at latitude 4deg S had coincided with the largest values of phylogeographic concordance, followed by a region characterized by the Vitoria-Trindade seamount chain and the Doce river outflow. The Cabo Frio seasonal upwelling system, although frequently pointed in literature as potential strong BGF, had low phylogeographic concordance. On the other hand, the meeting of the Malvinas' current with the Brazilian Current or the string of estuaries in south Brazil turned out to be a region of higher levels of BGF concordance even though such region is often not referred as a hotspot for genetic discontinuities.

According to Fine (2015) literature review and analysis, climate stability and the time-integrated area hypotheses alone are responsible for all marine and terrestrial LGD patterns observed in the world. Here we propose that a larger number of barriers to gene flow found in lower latitudes (and the processes responsible for this pattern), together with the climate stability and the time-integrated area hypotheses account for LGD, at least in the marine environment.

Due to the lack of studies at the extremes of the Brazilian coast, we could not test the effects of the Amazon river delta outflow and the Rio Grande do Sul long unconsolidated subtract extension as geographical BGF. Future phylogeographic papers will help improve the datasets and consequently the models produced in this study, allowing more spatially refined predictions of areas of high phylogeographic concordance, and the inclusion in our analyses of putative BGF located in the extreme northern and southern regions of Brazil. 


\section{Acknowledgements}

This study was funded by: Coordination for the Improvement of Higher Education Personnel (CAPES) Finance Code $001 \mathrm{PhD}$ fellowship to NTM. Santa Catarina State Research and Innovation Support Foundation (FAPESC) PhD fellowship to LBM. Sao Paulo Research Foundation (FAPESP) 2018/06085-1 to VC. The Brazilian National Council for Scientific and Technological Development (CNPq), PQ2 research grants 302549/2017-0 to VC; and 309658/2016-0 and 306304/2019-8 to CFDG, Universal grant 437115/2018-6 to CFDG. We thank the anonymous reviewers and the editor for important comments.

\section{References}

Andrade, S. C. S., Norenburg, J. L., \& Solferini, V. N. (2011). Worms without borders: Genetic diversity patterns in four Brazilian Ototyphlonemertes species (Nemertea, Hoplonemertea). Marine Biology , 158 , 2109-2124. doi: 10.1007/s00227-011-1718-3

Arbogast, B. S., \& Kenagy, G. J. (2001). Comparative phylogeography as an integrative approach to historical biogeography. Journal of Biogeography , 8 , 819-825. doi: 10.1046/j.1365-2699.2001.00594.x

Aron, S., \& Sole-Cava, A. (1991). Genetic evaluation of the taxonomic status of two varieties of the cosmopolitan ascidian Botryllus niger (Ascidiaceae: Botryllidae). Biochemical Systematics and Ecology , 19 , 271-276. doi: 10.1016/0305-1978(91)90014-Q

Arruda, C. C. B., Beasley, C. R., Vallinoto, M., Marques-Silva, N. do S., \& Tagliaro, C. H. (2009). Significant genetic differentiation among populations of Anomalocardia brasiliana (Gmelin, 1791): A bivalve with planktonic larval dispersion. Genetics and Molecular Biology , 32 , 423-430. doi: 10.1590/S141547572009000200033

Artico, L. O., Bianchini, A., Grubel, K. S., Monteiro, D. S., Estima, S. C., DeOliveira, L. R., ... Marins, L. F. (2010). Mitochondrial control region haplotypes of the South American sea lion Otaria flavescens (Shaw, 1800). Brazilian Journal of Medical and Biological Research , 43 , 816-820. doi: 10.1590/S0100879X2010007500074

Avise, J. C. (2000). Phylogeography - The history and formation of species. Cambridge, MA: Harvard University Press.

Avise, J. C., Arnold, J., Ball, R. M., Bermingham, E., Lamb, T., Neigel, J. E., ... Saunders, N. C. (1987). Intraspecific phylogeography: The mitochondrial DNA bridge between populations genetics and systematics. Annual Review of Ecology and Systematics , 18 , 489-522. doi: 10.1146/annurev.es.18.110187.002421

Ayres-Ostrock, L. M., Valero, M., Mauger, S., Oliveira, M. C., Plastino, E. M., Guillemin, M. L., \& Destombe, C. (2019). Dual influence of terrestrial and marine historical processes on the phylogeography of the Brazilian intertidal red alga Gracilaria caudata . Journal of Phycology , 55 , 1096-1114. doi: 10.1111/jpy. 12892

Beheregaray, L. B. (2008). Twenty years of phylogeography: The state of the field and the challenges for the Southern Hemisphere.Molecular Ecology , 17 , 3754-3774. doi: 10.1111/j.1365-294X.2008.03857.x

Beheregaray, L. B., \& Levy, J. A. (2000). Population genetics of the silverside Odontesthes argentinensis (Teleostei, Atherinopsidae): Evidence for speciation in an Estuary of Southern Brazil. Copeia ,2 , 441-447. doi: https://doi.org/10.1643/0045-8511(2000)000[0441:PGOTSO]2.0.CO;2

Beheregaray, L. B., \& Sunnucks, P. (2001). Fine-scale genetic structure, estuarine colonization and incipient speciation in the marine silverside fish Odontesthes argentinensis . Molecular Ecology , 10 , 2849-2866. doi: 10.1046/j.1365-294X.2001.t01-1-01406.x

Bezerra, I. M., Gramacho, K. P., Barreto, M. A., Hackradt, C. W., Leao Feitosa, J. L., Torres, R. A., ... Felix-Hackradt, F. C. (2018). Genetic diversity and gene flow of the threatened Brazilian en- 
demic parrotfish Scarus trispinosus (Valenciennes, 1840). Marine Environmental Research , 155-162. doi: 10.1016/j.marenvres.2018.10.004

Bilton, D. T., Paula, J., \& Bishop, J. D. D. (2002). Dispersal, genetic differentiation and speciation in estuarine organisms. Estuarine, Coastal and Shelf Science, 55 , 937-952. doi: 10.1006/ecss.2002.1037

Bowen, B. W., Shanker, K., Yasuda, N., Maria, M. C., Von Der Heyden, S., Paulay, G., .. Toonen, R. J. (2014). Phylogeography unplugged: Comparative surveys in the genomic era. Bulletin of Marine Science, 90 , 13-46. doi: 10.5343/bms.2013.1007

Byrne, M. (2008). Evidence for multiple refugia at different time scales during Pleistocene climatic oscillations in southern Australia inferred from phylogeography. Quaternary Science Reviews , 27 , 2576-2585. doi: $10.1016 / \mathrm{j}$.quascirev.2008.08.032

Calderon, I., Ventura, C. R. R., Turon, X., \& Lessios, H. A. (2010). Genetic divergence and assortative mating between colour morphs of the sea urchin Paracentrotus gaimardi . Molecular Ecology ,19 , 484-493. doi: $10.1111 / \mathrm{j} .1365-294 X .2009 .04506 . x$

Carmo, C. B., Ferrette, B. L. S., Camargo, S. M., Roxo, F. F., Coelho, R., Garla, R. C., .. Mendonca, F. F. (2019). A new map of the tiger shark (Galeocerdo cuvier) genetic population structure in the western Atlantic Ocean: Hypothesis of an equatorial convergence centre. Aquatic Conservation: Marine and Freshwater Ecosystems ,29 , 760-772. doi: 10.1002/aqc.3029

Cortinhas, M. C. da S., Kersanach, R., Proietti, M., Dumont, L. F. C., D'Incao, F., Lacerda, A. L. F., ... Cestari, M. M. (2016). Genetic structuring among silverside fish (Atherinella brasiliensis ) populations from different Brazilian regions. Estuarine, Coastal and Shelf Science , 178 , 148-157. doi: 10.1016/j.ecss.2016.06.007

Costa, A. P. B., Fruet, P., Daura-Jorge, F. G., Simoes-Lopes, P. C., Ott, P. H., Valiati, V. H., \& De Oliveira, L. R. (2015). Bottlenose dolphin communities from the southern Brazilian coast: Do they exchange genes or are they just neighbours? Marine and Freshwater Research , 66 , 1201-1210. doi: 10.1071/MF14007

da Silva, W. C., Marceniuk, A. P., Sales, J. B. L., \& Araripe, J. (2016). Early Pleistocene lineages of Bagre bagre (Linnaeus, 1766) (Siluriformes: Ariidae), from the Atlantic coast of South America, with insights into the demography and biogeography of the species.Neotropical Ichthyology , 14, e150184. doi: 10.1590/19820224-20150184

Dawson, M. N. (2013). Natural experiments and meta-analyses in comparative phylogeography. Journal of Biogeography , 41 , 52-65. doi: 10.1111/jbi.12190

de Oliveira, L. R., Fraga, L. D., Ott, P. H., Siciliano, S., Lopes, F., Almeida, R., ... Bonatto, S. L. (2019). Population structure, phylogeography, and genetic diversity of the common bottlenose dolphin in the tropical and subtropical southwestern Atlantic Ocean.Journal of Mammalogy , 100 , 564-577. doi: 10.1093/jmammal/gyz065

de Souza, T. O., Alves, F. A. dos S., Beasley, C. R., de Simone, L. R. L., Marques-Silva, N. do S., SantosNeto, G. da C., \& Tagliaro, C. H. (2015). Population structure and identification of two matrilinear and one patrilinear mitochondrial lineages in the mussel Mytella charruana . Estuarine, Coastal and Shelf Science, 156 (1), 165-174. doi: 10.1016/j.ecss.2014.11.009

Defeo, O. (1996). Recruitment variability in sandy beach macroinfauna: Much to learn yet. Revista Chilena de Historia Natural ,69 , 615-630.

Defeo, O., \& De Alava, A. (1995). Effects of human activities on long-term trends in sandy beach populations: The wedge clam Donax hanleyanus in Uruguay. Marine Ecology Progress Series ,123 , 73-82. doi: $10.3354 /$ meps 123073 
Diniz, F. M., Maclean, N., Ogawa, M., Cintra, I. H. A., \& Bentzen, P. (2005). The hypervariable domain of the mitochondrial control region in Atlantic spiny lobsters and its potential as a marker for investigating phylogeographic structuring. Marine Biotechnology , 7 , 462-473. doi: 10.1007/s10126-004-4062-5

Duarte, M., Ventura, C., \& Silva, E. (2016). Genetic variation in color morphs of the endangered species, Paracentrotus gaimardi(Echinoidea: Echinidae). Latin American Journal of Aquatic Research , 44, 46-55. doi: 10.3856/vol44-issue1-fulltext-5

Feliner, G. N. (2011). Southern European glacial refugia: A tale of tales. Taxon , 60 , 365-372. doi: $10.1002 / \operatorname{tax} .602007$

Fine, P. V. A. (2015). Ecological and evolutionary drivers of geographic variation in species diversity. Annual Review of Ecology, Evolution, and Systematics , 46 , 369-392. doi: 10.1146/annurev-ecolsys-112414-054102

Francisco, P. M., Mori, G. M., Alves, F. M., Tambarussi, E. V., \& de Souza, A. P. (2018). Population genetic structure, introgression, and hybridization in the genus Rhizophora along the Brazilian coast.Ecology and Evolution , 8 , 3491-3504. doi: 10.1002/ece3.3900

Fruet, P. F., Secchi, E. R., Daura-Jorge, F., Vermeulen, E., Flores, P. A. C., Simoes-Lopes, P. C., .. Moller, L. M. (2014). Remarkably low genetic diversity and strong population structure in common bottlenose dolphins (Tursiops truncatus) from coastal waters of the Southwestern Atlantic Ocean. Conservation Genetics ,15 , 879-895. doi: 10.1007/s10592-014-0586-z

Grant, W. S., \& Bowen, B. W. (1998). Shallow population histories in deep evolutionary lineages of marine fishes: Insights from sardines and anchovies and lessons for conservation. Journal of Heredity ,89 , 415-426. doi: $10.1093 /$ jhered/89.5.415

Guralnick, R. (2006). The legacy of past climate and landscape change on species'current experienced climate and elevation ranges across latitude: A multispecies study utilizing mammals in western North America. Global Ecology and Biogeography , 15 , 505-518. doi: 10.1111/j.1466-822X.2006.00231.x

Gurgel, C. F. D., Fredencq, S., \& Norris, J. N. (2004). Phylogeography of Gracilaria tikvahiae (Gracilariaceae, Rhodophyta): A study of genetic discontinuity in a continuously distributed species based on molecular evidence. Journal of Phycology , 40 , 748-758. doi: 10.1111/j.1529-8817.2004.03070.x

Hickerson, M. J., Carstens, B. C., Cavender-Bares, J., Crandall, K. A., Graham, C. H., Johnson, J. B., ... Yoder, A. D. (2010). Phylogeography's past, present, and future: 10 years after Avise, 2000.Molecular Phylogenetics and Evolution , 54 , 291-301. doi: 10.1016/j.ympev.2009.09.016

Hurtado, L. A., Mateos, M., Mattos, G., Liu, S., Haye, P. A., \& Paiva, P. C. (2016). Multiple transisthmian divergences, extensive cryptic diversity, occasional long-distance dispersal, and biogeographic patterns in a marine coastal isopod with an amphi-American distribution.Ecology and Evolution , 6 , 7794-7808. doi: $10.1002 /$ ece3.2397

Imron, Jeffrey, B., Hale, P., Degnan, B. M., \& Degnan, S. M. (2007). Pleistocene isolation and recent gene flow in Haliotis asinina, an Indo-Pacific vetigastropod with limited dispersal capacity.Molecular Ecology , 16 , 289-304. doi: 10.1111/j.1365-294X.2006.03141.x

Jablonski, D., Huang, S., Roy, K., \& Valentine, J. W. (2017). Shaping the latitudinal diversity gradient: New perspectives from a synthesis of paleobiology and biogeography. American Naturalist , 189 , 1-12. doi: $10.1086 / 689739$

Kinlan, B. P., \& Gaines, S. D. (2003). Propagule dispersal in marine and terrestrial environments: A community perspective. Ecology ,84 , 2007-2020. doi: 10.1890/01-0622

Lazoski, C., Gusmao, J., Boudry, P., \& Sole-Cava, A. M. (2011). Phylogeny and phylogeography of Atlantic oyster species: Evolutionary history, limited genetic connectivity and isolation by distance.Marine Ecology Progress Series , 426 , 197-212. doi: 10.3354/meps09035 
Lorenzen, E. D., Heller, R., \& Siegismund, H. R. (2012). Comparative phylogeography of African savannah ungulates. Molecular Ecology ,21 , 3656-3670. doi: 10.1111/j.1365-294X.2012.05650.x

Machado, L. F., Damasceno, J. de S., Bertoncini, A. A., Tosta, V. C., Farro, A. P. C., Hostim-Silva, M., \& Oliveira, C. (2017). Population genetic structure and demographic history of the spadefish, Chaetodipterus faber (Ephippidae) from Southwestern Atlantic.Journal of Experimental Marine Biology and Ecology , 487 , 45-52. doi: 10.1016/j.jembe.2016.11.005

Maggioni, R., Rogers, A. D., \& Maclean, N. (2003). Population structure of Litopenaeus schmitti (Decapoda: Penaeidae) from the Brazilian coast identified using six polymorphic microsatellite loci.Molecular Ecology , 12 , 3213-3217. doi: 10.1046/j.1365-294X.2003.01987.x

Marigo, J., Cunha, H. A., Bertozzi, C. P., Souza, S. P., Rosas, F. C. W., Cremer, M. J., .. Vicente, A. C. P. (2015). Genetic diversity and population structure of Synthesium pontoporiae (Digenea, Brachycladiidae) linked to its definitive host stocks, the endangered Franciscana dolphin, Pontoporia blainvillei(Pontoporiidae) off the coast of Brazil a. Journal of Helminthology , 89 , 19-27. doi: 10.1017/S0022149X13000540

Mendonca, F. F., Oliveira, C., Gadig, O. B. F., \& Foresti, F. (2011). Phylogeography and genetic population structure of Caribbean sharpnose shark Rhizoprionodon porosus . Reviews in Fish Biology and Fisheries, 21 , 799-814. doi: 10.1007/s11160-011-9210-1

Mittelbach, G. G., Schemske, D. W., Cornell, H. V., Allen, A. P., Brown, J. M., Bush, M. B., .. Turelli, M. (2007). Evolution and the latitudinal diversity gradient: Speciation, extinction and biogeography.Ecology Letters , 10 , 315-331. doi: 10.1111/j.1461-0248.2007.01020.x

Molinari, R. L. (1983). Observations of near-surface currents and temperature in the central and western tropical. Journal of Geophysical Research , 88 , 4433-4438. doi: 10.1029/JC088iC07p04433

Montes, M. A., Cardoso, M. L. V., Neves, C. H. C. B., Garcia, A. C. L., Da Silva, J. C., \& Silveira, R. B. (2018). Genetic diversity and populational structure of the seahorse Hippocampus reidi(Syngnathidae) in north-eastern Brazil: A conservationist approach.Aquatic Conservation: Marine and Freshwater Ecosystems ,28 , 1114-1122. doi: 10.1002/aqc.2919

Mori, G. M., Zucchi, M. I., Sampaio, I., \& Souza, A. P. (2015). Species distribution and introgressive hybridization of two Avicenniaspecies from the Western Hemisphere unveiled by phylogeographic patterns Phylogenetics and phylogeography. BMC Evolutionary Biology ,15 , 1-15. doi: 10.1186/s12862-015-0343-z

Nauer, F., Gurgel, C. F. D., Ayres-Ostrock, L. M., Plastino, E. M., \& Oliveira, M. C. (2019). Phylogeography of the Hypnea musciformisspecies complex (Gigartinales, Rhodophyta) with the recognition of cryptic species in the western Atlantic Ocean. Journal of Phycology , 55 ,676-687. doi: 10.1111/jpy.12848

Nunes, F. L. D., Norris, R. D., \& Knowlton, N. (2011). Long distance dispersal and connectivity in AmphiAtlantic corals at regional and basin scales. PLoS ONE , 6 , e22298. doi: 10.1371/journal.pone.0022298

Olson, D. M., Dinerstein, E., Wikramanayake, E. D., Burgess, N. D., Powell, G. V. N., Underwood, E. C., ... Kassem, K. R. (2001). Terrestrial ecoregions of the World: a new map of life on Earth.BioScience, 11 , 933-938. doi: 10.1641/0006-3568(2001)051[0933:teotwa]2.0.co;2

Paiva, P. C., Mutaquilha, B. F., Coutinho, M. C. L., \& Santos, C. S. G. (2019). Comparative phylogeography of two coastal species of Perinereis Kinberg, 1865 (Annelida, Polychaeta) in the South Atlantic. Marine Biodiversity , 49 , 1537-1551. doi: 10.1007/s12526-018-0927-0

Pazoto, C., Ventura, C., Duarte, M., \& Silva, E. (2018). Genetic variation and population homogeneity of the sea starCoscinasterias tenuispina (Forcipulatida: Asteroidea) on the coast of Rio de Janeiro, Brazil. Latin American Journal of Aquatic Research , 46 , 355-363. doi: 10.3856/vol46-issue2-fulltext-11

Pellegrino, K. C. M., Rodrigues, M. T., Waite, A. N., Morando, M., Yassuda, Y. Y., \& Sites, J. W. (2005). Phylogeography and species limits in the Gymnodactylus darwinii complex (Gekkonidae, Squamata): Genetic 
structure coincides with river systems in the Brazilian Atlantic Forest. Biological Journal of the Linnean Society , 85 , 13-26. doi: 10.1111/j.1095-8312.2005.00472.x

Peluso, L., Tascheri, V., Nunes, F. L. D., Castro, C. B., Pires, D. O., \& Zilberberg, C. (2018). Contemporary and historical oceanographic processes explain genetic connectivity in a Southwestern Atlantic coral.Scientific Reports , 8 , 1-12. doi: 10.1038/s41598-018-21010-y

Peterson, B., Weber, J., Kay, E., Fisher, H., \& Hoekstra, H. (2012). Double digest RADseq: An inexpensive method for de novo SNP discovery and genotyping in model and non-model species. PLoS ONE, e37135. doi: $10.1371 /$ journal.pone.0037135

Peterson, R., \& Stramma, L. (1991). Upper-level circulation in the South Atlantic Ocean. Progress in Oceanography , 26 , 1-73. doi: 10.1016/0079-6611(91)90006-8

Pfenninger, M., Posada, D., \& Magnin, F. (2003). Evidence for the survival of the Pleistocene climatic change in Northern refugia by the land snail Trochoidea geyeri (Soos 1926). BMC Evol. Biol. ,77, 30-40. doi: $10.1186 / 1471-2148-3-8$

Pianka, E. R. (1966). Latitudinal gradients in species diversity: A review of concepts. The American Naturalist , 100 , 33-46. doi: 10.1086/282398

Pil, M. W., Boeger, M. R. T., Muschner, V. C., Pie, M. R., Ostrensky, A., \& Boeger, W. A. (2011). Postglacial north-south expansion of populations of Rhizophora mangle (Rhizophoraceae) along the Brazilian coast revealed by microsatellite analysis. American Journal of Botany , 98 , 1031-1039. doi: $10.3732 /$ ajb. 1000392

Proietti, M. C., Reisser, J., Marins, L. F., Rodriguez-Zarate, C., Marcovaldi, M. A., Monteiro, D. S., ... Secchi, E. R. (2014). Genetic structure and natal origins of immature hawksbill turtles (Eretmochelys imbricata) in Brazilian waters. PLoS ONE ,9 , e88746. doi: 10.1371/journal.pone.0088746

Puchnick-Legat, A., \& Levy, J. A. (2006). Genetic structure of Brazilian populations of white mouth croaker Micropogonias furnieri (Perciformes: Sciaenidae). Brazilian Archives of Biology and Technology , 49 , 429439. doi: 10.1590/S1516-89132006000400011

R Core Team. (2020). R: A language and environment for statistical computing. Retrieved from R Foundation for Statistical Computing website: http://www.r-project.org/

Randso, P. V., Domenico, M. D., Herranz, M., Lorenzen, E. D., \& Sorensen, M. V. (2018). Population genetic structure of the intertidal kinorhynch Echinoderes marthae (Kinorhyncha; Cyclorhagida; Echinoderidae) across the Sao Sebastiao Channel, Brazil.Proceedings of the Biological Society of Washington , 131 , 36-46. doi: 10.2988/17-00005

Reeb, C. A., \& Avise, J. C. (1990). A genetic discontinuity in a continuously distributed species: Mitochondrial DNA in the American oyster, Crassostrea virginica . Genetics , 124, 397-406.

Reis, E. C., Soares, L. S., Vargas, S. M., Santos, F. R., Young, R. J., Bjorndal, K. A., .. LoboHajdu, G. (2010). Genetic composition, population structure and phylogeography of the loggerhead sea turtle: Colonization hypothesis for the Brazilian rookeries. Conservation Genetics , 11 , 1467-1477. doi: $10.1007 / \mathrm{s} 10592-009-9975-0$

Rocha, L. A., Craig, M. T., \& Bowen, B. W. (2007). Phylogeography and the conservation of coral reef fishes. Coral Reefs , 26 , 501-512. doi: 10.1007/s00338-007-0261-7

Rodrigues, R., Santos, S., Haimovici, M., Saint-Paul, U., Sampaio, I., \& Schneider, H. (2014). Mitochondrial DNA reveals population structuring in Macrodon atricauda (Perciformes: Sciaenidae): A study covering the whole geographic distribution of the species in the southwestern Atlantic. Mitochondrial DNA , 25 , 150-156. doi: $10.3109 / 19401736.2013 .792053$ 
Russo, C. de M., \& Sole-Cava, A. (1991). High levels of gene variation and the population structure of Bunodosoma caissarum (Cnidaria : Actiniidae). Revista de Biologia Tropical , 39 , 41-46. doi: $10.15517 /$ rbt.v39i1.24568

Santos, S., Hrbek, T., Farias, I. P., Schneider, H., \& Sampaio, I. (2006). Population genetic structuring of the king weakfish,Macrodon ancylodon (Sciaenidae), in Atlantic coastal waters of South America: Deep genetic divergence without morphological change.Molecular Ecology , 15 , 4361-4373. doi: 10.1111/j.1365294X.2006.03108.x

Satler, J. D., \& Carstens, B. C. (2016). Phylogeographic concordance factors quantify phylogeographic congruence among co-distributed species in the Sarracenia alata pitcher plant system. Evolution ,70 , 1105-1119. doi: 10.1111/evo.12924

Secchi, E. R., Wang, J. Y., Murray, B. W., Rocha-Campos, C. C., \& White, B. N. (1998). Population differentiation in the franciscana (Pontoporia blainvillei) from two geographic locations in Brazil as determined from mitochondrial DNA control region sequences.Canadian Journal of Zoology , 76 , 1622-1627. doi: $10.1139 /$ z98-099

Shafer, A. B. A., Cullingham, C. I., Cote, S. D., \& Coltman, D. W. (2010). Of glaciers and refugia: A decade of study sheds new light on the phylogeography of northwestern North America. Molecular Ecology , 19 , 4589-4621. doi: 10.1111/j.1365-294X.2010.04828.x

Siccha-Ramirez, Z. R., Maroso, F., Pardo, B. G., Fernandez, C., Martinez, P., \& Oliveira, C. (2018). SNP identification and validation on genomic DNA for studying genetic diversity in Thunnus albacares and Scomberomorus brasiliensis by combining RADseq and long read high throughput sequencing. Fisheries Research ,198 , 189-194. doi: 10.1016/j.fishres.2017.09.002

Soltis, D. E., Morris, A. B., McLachlan, J. S., Manos, P. S., \& Soltis, P. S. (2006). Comparative phylogeography of unglaciated eastern North America. Molecular Ecology , 15 , 4261-4293. doi: 10.1111/j.1365294X.2006.03061.x

Spalding, M. D., Fox, H. E., Allen, G. R., Davidson, N., Ferdana, Z. A., Finlayson, M., .. Robertson, J. (2007). Marine ecoregions of the world: A bioregionalization of coastal and shelf areas.BioScience , 57, 573-583. doi: 10.1641/b570707

Stebbins, L. C. (1974). Flowering plants: evolution above the species level . Cambridge, MA: Belknap Press of Harvard University Press.

Stevens, G. C. (1989). The latitudinal gradient in geographical range: how so many species coexist in the tropics. American Naturalist ,133 , 240-256. doi: 10.1086/284913

Stramma, L., \& England, M. (1999). On the water masses and mean circulation of the South Atlantic Ocean. Journal of Geophysical Research , 104 , 22863-20883. doi: 10.1029/1999jc900139

Taberlet, P., Fumagalli, L., Wust-Saucy, A. G., \& Cosson, J. F. (1998). Comparative phylogeography and postglacial colonization routes in Europe. Molecular Ecology , 7 , 453-464. doi: 10.1046/j.1365294x.1998.00289.x

Teske, P. R., Sandoval-Castillo, J., Waters, J., \& Beheregaray, L. B. (2017). An overview of Australia's temperate marine phylogeography, with new evidence from high-dispersal gastropods. Journal of Biogeography , 44 , 217-229. doi: $10.1111 /$ jbi.12783

Trewick, S. A., Morgan-Richards, M., Russell, S. J., Henderson, S., Rumsey, F. J., Pinter, I., .. Vogel, J. C. (2002). Polyploidy, phylogeography and Pleistocene refugia of the rockfern Asplenium ceterach : Evidence from chloroplast DNA. Molecular Ecology ,11 , 2003-2012. doi: 10.1046/j.1365-294X.2002.01583.x

Trovant, B., Basso, N. G., Orensanz, J. M., Lessa, E. P., Dincao, F., \& Ruzzante, D. E. (2016). Scorched mussels (Brachidontes spp., Bivalvia: Mytilidae) from the tropical and warm-temperate southwestern At- 
lantic: The role of the Amazon River in their speciation.Ecology and Evolution , 6 , 1778-1798. doi: 10.1002/ece3.2016

Turchetto-Zolet, A. C., Pinheiro, F., Salgueiro, F., \& Palma-Silva, C. (2013). Phylogeographical patterns shed light on evolutionary process in South America. Molecular Ecology , 22 , 1193-1213. doi: 10.1111/mec.12164

Valentin, J. L., Andre, D. L., \& Jacob, S. A. (1987). Hydrobiology in the Cabo Frio (Brazil) upwelling: two-dimensional structure and variability during a wind cycle. Continental Shelf Research ,7 , 77-88. doi: 10.1016/0278-4343(87)90065-3

Vasconcellos, A. V. de, Lima, D., Bonhomme, F., Vianna, M., \& Sole-Cava, A. M. (2015). Genetic population structure of the commercially most important demersal fish in the Southwest Atlantic: The whitemouth croaker (Micropogonias furnieri ). Fisheries Research , 167 , 333-337. doi: 10.1016/j.fishres.2015.03.008

Verbruggen, H., Tyberghein, L., Pauly, K., Vlaeminck, C., Nieuwenhuyze, K. Van, Kooistra, W. H. C. F. C. F., ... de Clerck, O. (2009). Macroecology meets macroevolution: Evolutionary niche dynamics in the seaweed Halimeda . Global Ecology and Biogeography ,18 , 393-405. doi: 10.1111/j.1466-8238.2009.00463.x

Wangensteen, O. S., Turon, X., Perez-Portela, R., \& Palacin, C. (2012). Natural or naturalized? Phylogeography suggests that the abundant sea urchin Arbacia lixula is a recent colonizer of the Mediterranean.PLoS ONE , 7 , 1-16. doi: 10.1371/journal.pone.0045067

Wares, J. P., Gaines, S., \& Cunningham, C. W. (2001). A comparative study of asymmetric migration events across a marine biogeographic boundary. Evolution , 55 , 295-306. doi: 10.1111/j.0014-3820.2001.tb01294.x

Weber, L. I., \& Levy, J. A. (2000). Genetic population structure of the swimming crab Callinectes danae (Crustacea: Decapoda) in southern Brazil. Hydrobiologia , 420 , 203-210. doi: 10.1023/A:1003992630229

Wood, S. N. N. (2017). Generalized additive models: An introduction with R. In Generalized Additive Models: An Introduction with $R$ (2nd ed.). doi: 10.1201/9781315370279

Zar, J. H. (1999). Biostatistical analysis . India: Pearson Education India.

\section{Data Accessibility}

The data accessibility was submitted as Supplemental material.

Table S1: Data matrix built from genetic discontinuities empirical data extracted from scientific papers published between 1987-2019 with sample sites within the Brazilian coast

\section{Authors Contributions}

Conception and design of the research: NTM, VC, CFDG

Data collection and literature search: NTM, LBM, CFDG

Dataset preparation, data analysis and interpretation: NTM, LBM, VC, CFDG

Drafting the article: NTM, LBM, VC, CFDG

\section{Figures captions}

Figure 1. Maps of the Brazilian coast. (A) Present time. Different colors indicate different phylogeographic Regions I-IV. Political states identified as their official 2-letter code. = mouth of major rivers. = VitoriaTrindade seamount chain. = Cabo Frio upwelling system. = Cassino beach, the longest sandy beach in the southern hemisphere. SEC = South Equatorial Current. (B) Current and past coastline during Pleistocene glacial maxima with sea level 100 meters lower than present time. Bathymetry legend corresponds to figure 1B only. Boundary current according to R. Peterson \& Stramma (1991). 
Figure 2. Number of molecular-driven marine phylogeography papers published between 1987 and 2019 that minimally addressed Brazil's marine biota.

Figure 3. Percentage of number of molecular-driven marine phylogeography papers published between 1987 and 2019 that minimally addressed Brazil's marine biota according to (A) types of genetic markers (fragment analysis stands for ddRAD, RAPD, ISSR, AFLP, and RFLP techniques), (B) taxonomic groups, (C) functional forms and, (D) marine habitat.

Figure 4: Generalized linear model applied of the frequency of putative barriers to gene flow occurrences for populations of marine species recorded along the Brazilian coast (in latitudes). Data collected from articles contained new molecular data published between 1991 and 2019 with sample sites within the Brazilian coast.

Figure 5: Generalized additive model for the frequency of putative barriers to gene flow occurrences for populations of marine species sampled along the Brazilian coast. Data collected from phylogeography papers published between 1991 and 2019. Roman numbers stands for each of the four phylogeographic regions recognized in this model.

Figure 6: Phylogeographic break frequency at phylogeographic Regions I-IV identified in the generalized linear model depicted in Figure 5. The line within the box marks the median. The boundary of the box indicates the $25^{\text {th }}$ and $75^{\text {th }}$ percentiles. Vertical line indicate the $10^{\text {th }}$ and $90^{\text {th }}$ percentiles. Whiskers above and below the box indicate outliers outside the 10th and 90th percentiles. Different letters above the box indicate statistically significant differences $(\mathrm{p}<0.05)$.

Figure 7: Generalized additive models for the frequency of putative barriers to gene flow frequencies for populations of different marine taxa recorded along the Brazilian coast. Data collected from phylogeography papers published between 1991 and 2019 with sample sites within the Brazilian coast. A) Fishes, B) Crustaceans, C) Mollusks and, D) Cnidarians. Images represents an example of each taxonomic group. Graphs were designed using resources from flaticon.com.

Table 1: Top five journals with the largest number of empirical articles containing phylogeographic data on Brazilian marine species.

\begin{tabular}{ll}
\hline Journal & Number of articles \\
\hline PLoS ONE & 12 \\
Journal of Experimental Marine Biology and Ecology & 11 \\
Genetics and Molecular Biology & 8 \\
Marine Biology & 8 \\
Molecular Ecology & 6 \\
Total number of Journals & 74 \\
\hline
\end{tabular}

Table 2: Number of studies per Brazilian geopolitical states per taxonomic groups extracted from scientific articles published between 1987-2019.

\begin{tabular}{llllllllll}
\hline Region & North & North & Northeast & Northeast & Northeast & Northeast & Northeast & Northeast & Northeast \\
\hline State & AP & PA & MA & PI & CE & RN & PB & PE & AL \\
Ascidiacea & 0 & 0 & 0 & 0 & 0 & 0 & 0 & 0 & 0 \\
Aves & 1 & 2 & 1 & 1 & 0 & 0 & 0 & 0 & 0 \\
Cetacea & 0 & 2 & 0 & 0 & 3 & 1 & 0 & 0 & 0 \\
Cnidaria & 0 & 0 & 1 & 0 & 3 & 2 & 7 & 5 & 4 \\
Crustacea & 4 & 10 & 9 & 1 & 11 & 8 & 0 & 12 & 7 \\
Echinodermata & 0 & 0 & 0 & 0 & 0 & 0 & 0 & 0 & 0 \\
Fishes & 4 & 17 & 8 & 1 & 15 & 26 & 6 & 12 & 1 \\
Kinorhynch & 0 & 0 & 0 & 0 & 0 & 0 & 0 & 0 & 0
\end{tabular}




\begin{tabular}{llllllllll}
\hline Region & North & North & Northeast & Northeast & Northeast & Northeast & Northeast & Northeast & Northeast \\
\hline Mollusca & 3 & 6 & 1 & 1 & 6 & 5 & 6 & 8 & 2 \\
Nemertea & 0 & 0 & 0 & 0 & 0 & 0 & 0 & 0 & 0 \\
Otariidae & 0 & 0 & 0 & 0 & 0 & 0 & 0 & 0 & 0 \\
Plantae & 0 & 6 & 4 & 3 & 4 & 3 & 1 & 4 & 0 \\
Platyhelminthes & 0 & 0 & 0 & 0 & 0 & 0 & 0 & 0 & 0 \\
Polychaeta & 0 & 0 & 0 & 0 & 3 & 0 & 2 & 3 & 0 \\
Porifera & 0 & 0 & 0 & 0 & 0 & 0 & 0 & 1 & 0 \\
Testudinata & 0 & 0 & 0 & 0 & 2 & 1 & 0 & 0 & 0 \\
Total & 12 & 43 & 24 & 7 & 47 & 46 & 22 & 45 & 14 \\
\hline
\end{tabular}

Table S1: Data matrix built from genetic discontinuities empirical data extracted from scientific papers published between 1987-2019 with sample sites within the Brazilian coast
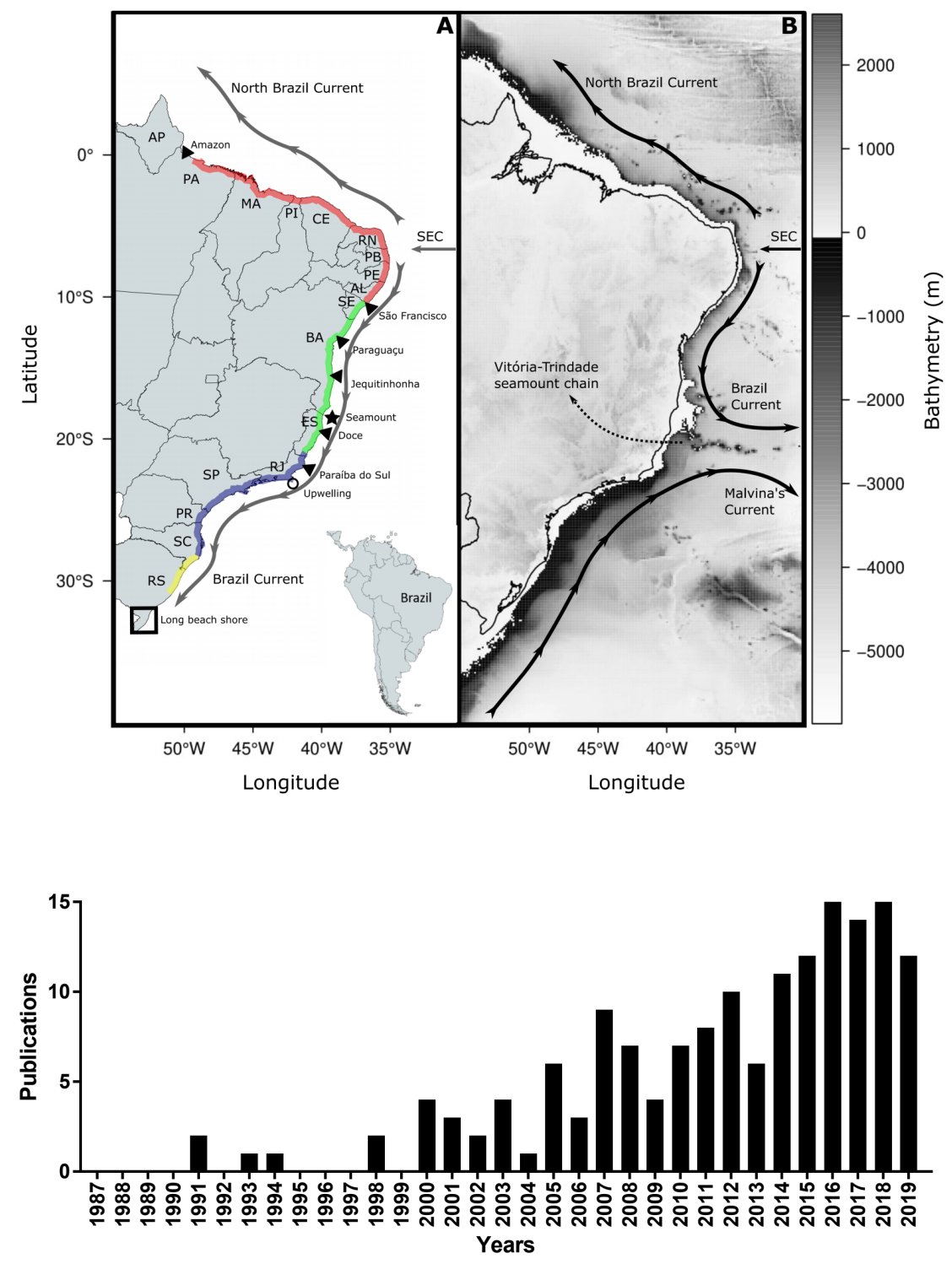

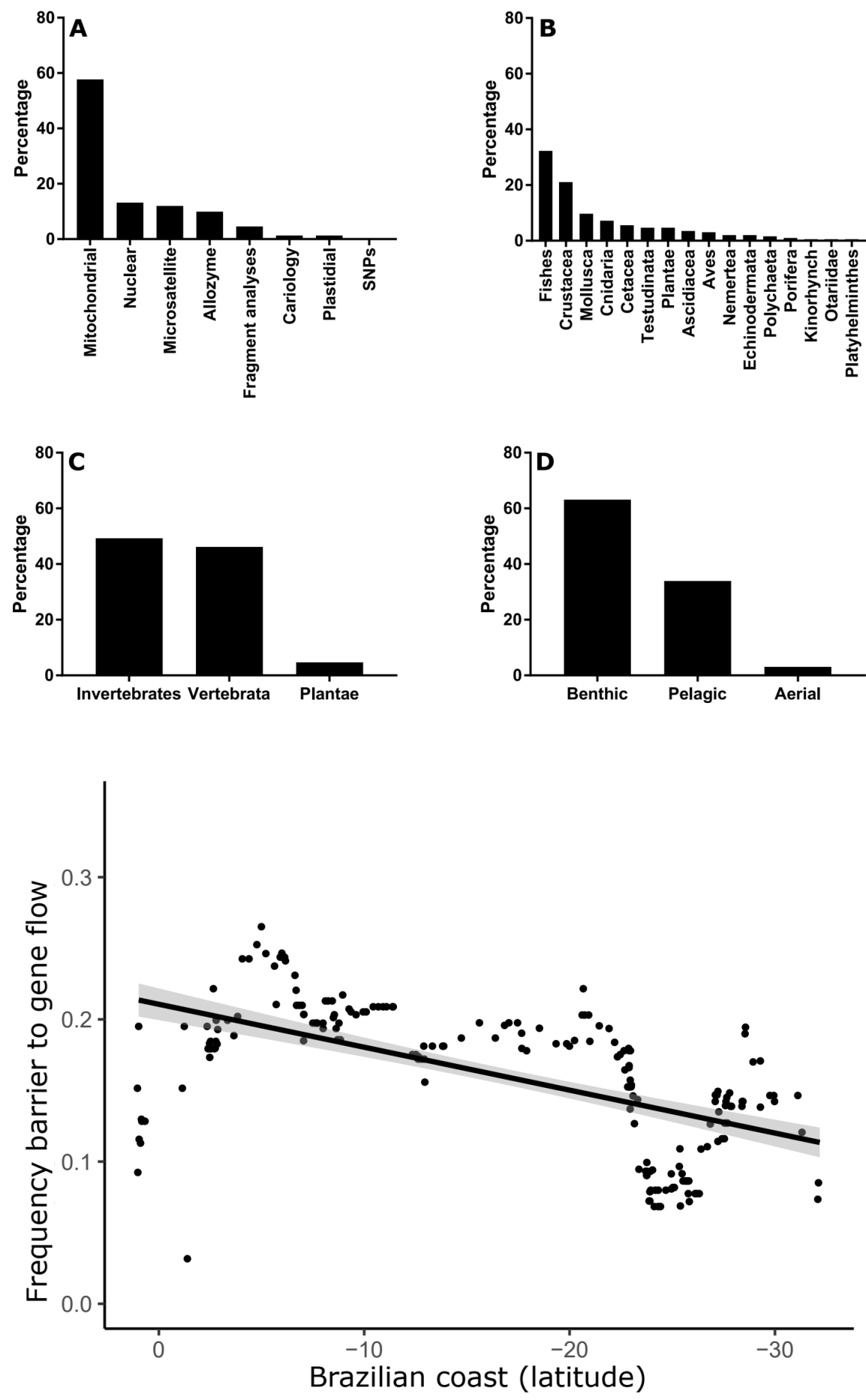

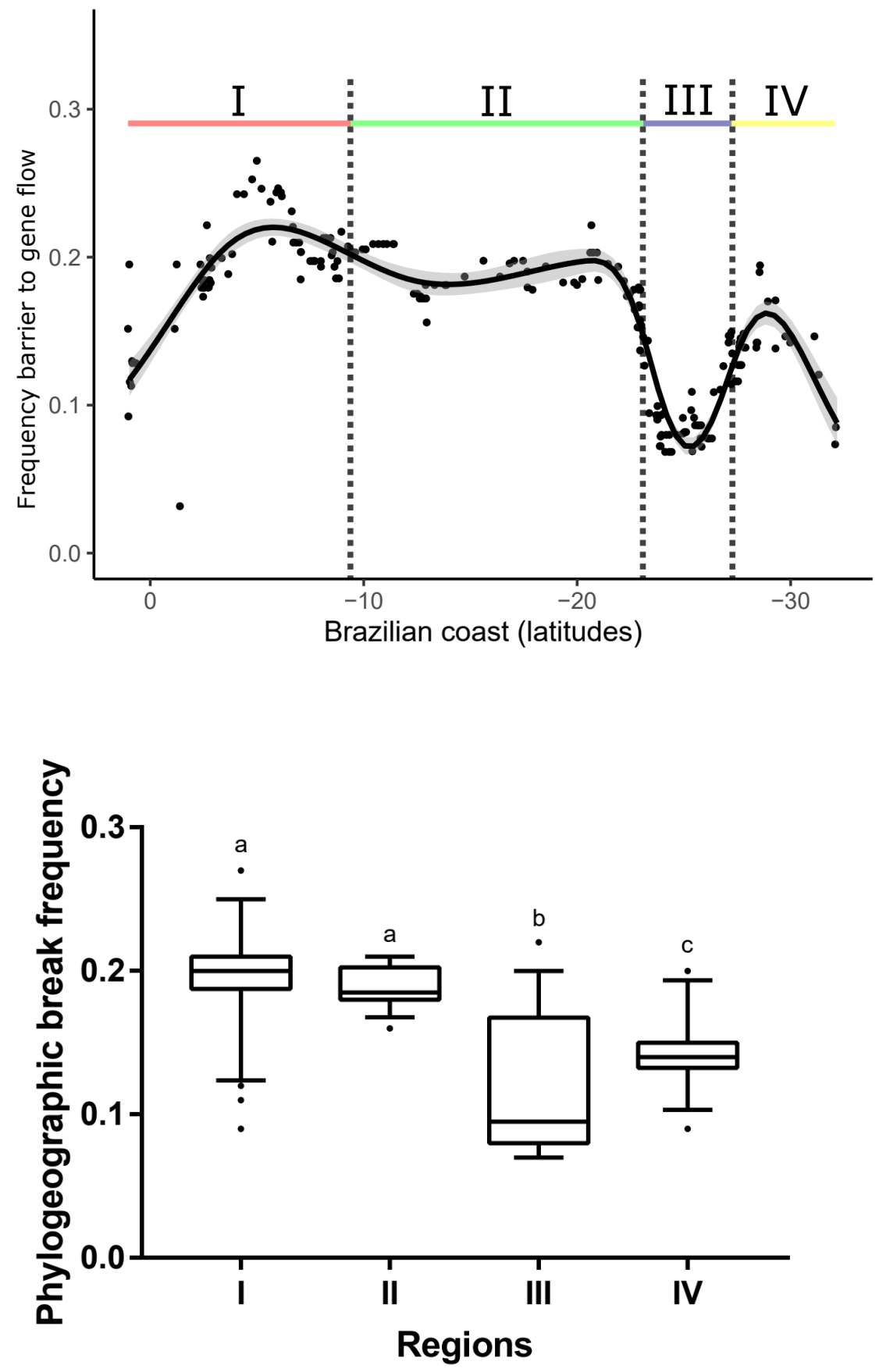

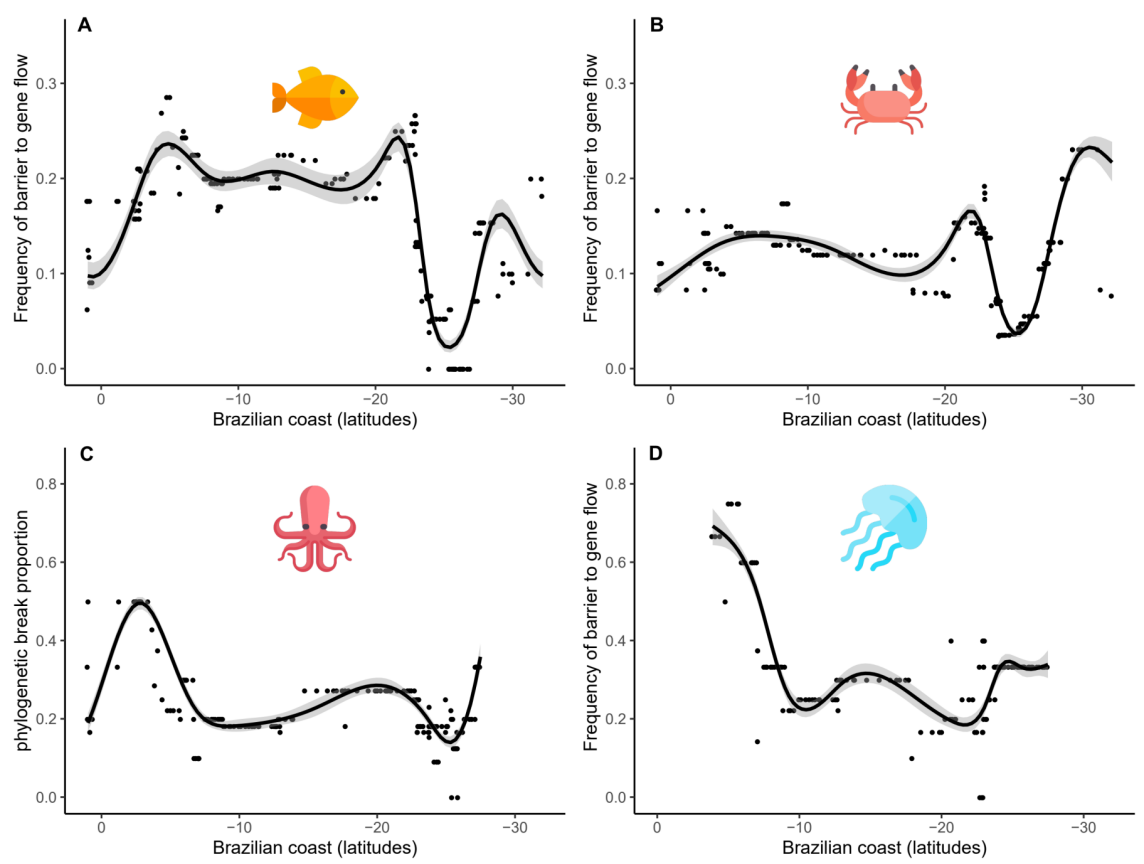